\title{
DAMPAK PERTUKARAN ATASAN DAN BAWAHAN TERHADAP PERILAKU KETERIKATAN KERJA DENGAN PERASAAN KEWAJIBAN SEBAGAI PEMEDIASI DAN IDEOLOGI PERTUKARAN SEBAGAI PEMODERASI
}

\author{
I Gede Krisna Sukma Putra ${ }^{1}$, Rio Dhani Laksana ${ }^{2 *}$ \\ ${ }^{1}$ Fakultas Ekonomika dan Bisnis, Universitas Gadjah Mada, Indonesia \\ ${ }^{2}$ Fakultas Ekonomi dan Bisnis, Universitas Jenderal Soedirman, Indonesia \\ *Email corresponding author: riodhani@unsoed.ac.id \\ Received 02/09/2020 Direvisi 22/01/2021 Diterbitkan 31/01/2021
}

\begin{abstract}
Abstrak
Penelitian ini ditujukan untuk mengamati dampak yang ditimbulkan antara atasan dan bawahan yang ditukar dengan perilaku keterikatan kerja melalui mediasi perasaan kewajiban dan adanya moderasi dari ideologi pertukaran. Sebanyak 224 responden berpartisipasi dalam penelitian ini, mereka merupakan pegawai pada Badan Pemeriksa Keuangan (BPK). Untuk mengumpulkan data, metode yang digunakan adalah metode survei dengan media kuesioner yang diadministrasikan sendiri (langsung dan daring). Penelitian ini menggunakan metode regresi bertingkat (hierarchical regression) untuk hipotesis 1 dan 2 dan Moderated Regression Analysis (MRA) Hasil penelitian memperlihatkan bahwa atasan dan bawahan yang ditukar akan berdampak terhadap perilaku keterikatan kerja dengan mediasi parsial dari perasaan kewajiban. Namun ideologi pertukaran terbukti tidak memiliki efek pemoderasi dalam hubungan antara pertukaran atasan dan bawahan terhadap perasaan kewajiban. Implikasi dari penelitian ini adalah: (1) mediasi parsial dari perasaan kewajiban mengindikasikan adanya hubungan langsung antara pertukaran atasan dan bawahan terhadap keterikatan kerja dan dimungkinkan adanya variabel-variabel lain yang dapat memediasi, di luar variabel-variabel yang diuji dalam penelitian ini, dan (2) ideologi pertukaran tidak memiliki efek pemoderasi, hal ini memperlihatkan indikasi adanya kemungkinan hubungan langsung antara ideologi pertukaran dengan perasaan kewajiban serta pertukaran atasan dan bawahan. Manajer dan organisasi perlu untuk mempertimbangkan bagaimana cara untuk meningkatkan kualitas dari hubungan pertukaran atasan dan bawahan yang dapat meningkatkan keterikatan kerja karyawan. Mereka juga perlu memperhatikan ideologi pertukaran yang dimiliki oleh karyawan karena dimungkinkan dapat berpengaruh langsung terhadap perasaan kewajiban serta pertukaran atasan dan bawahan.
\end{abstract}

Kata Kunci: Atasan dan Bawahan yang Ditukar, Keterikatan Kerja, Perasaan Kewajiban, Ideologi Pertukaran.

\footnotetext{
Abstract

This research is directed to examine the impact of Leader-Member Exchange (LMX) towards work engagement through the mediation of felt obligation and the moderation of exchange ideology. There are 214 respondents participated in this research, whose are employees at the Audit Board of the Republic of Indonesia. Data collection on this research is used selfadministered questionnaire method (offline and online). The result shows that LMX has impact toward work engagement through partially mediation of felt obligation. But exchange ideology fails to moderated the influence of LMX toward felt obligation. The hint of this research are: (1) partially mediation of felt obligation shows an indication that LMX has direct impact toward work engagement and there is possibility of another mediation variables between two variables which not tested on this research, and (2) exchange ideology does not have moderation effect, shows that there is possibility direct effect of exchange ideology toward felt obligation and LMX, also there is possibility that respondents are saw the exchange relationship in organizational contexts which can reduce their norm of reciprocity (e.g. exchange ideology). Managers and organization need to consider how to enhance the quality of LMX which could increase the work engagement of their employees. They also need to pay
} 
Performance. Volume 28 Nomor 1 Tahun 2021, 41-53

attention to others variables that could mediating the impact of exchange relationship toward work engagement. They are also need to pay attention to exchange ideology within their employees because it could have negative direct effect toward felt obligation and LMX.

Key Words: LMX, Work Engagement, Felt Obligation, Exchange Ideology.

\section{PENDAHULUAN}

Teori pertukaran sosial (social exchange theory) (Blau, 1964) menyatakan bahwa terjadi hubungan resiprokal antara atasan dan bawahan. Hubungan antara atasan dengan bawahan akan terjadi hubungan diadik unik yang terbentuk dari proses pembentukan peran yang berdampak pada sikap kerja dan perilaku individu di dalam hubungan pertukaran tersebut (Breevaart et al., 2013). Dalam beberapa studi meta-analisis dan studi empiris, diketahui bahwa kualitas hubungan pertukaran atasan dan bawahan akan berpengaruh kepada keluaran positif dari bawahan (e.g. kepuasan kerja, kinerja, perilaku kewargaan organisasional, keterikatan kerja, komitmen, kejelasan peran, dan perilaku kerja inovatif) (Ilies et al., 2007; Dulebohn et al., 2012; Breevaart et al., 2013; Meng \& Wu, 2015; Gutermann et al., 2017; Laksana et al.2020). Mutu korelasi antara pertukaran atasan dan bawahan yang tinggi diasumsikan akan berdampak pada terciptanya keterikatan kerja karyawan dan dapat meningkatkan kinerja karyawan (Rich et al., 2010). Rich et al. (2010) juga berpendapat bahwa keterikatan kerja memiliki imbas terbesar terhadap kinerja individu jika dikomparasikan dengan variabel-variabel lainnya (e.g. keterlibatan kerja, kepuasan kerja, dan motif intrinsik).

Breevart et al. (2013) dan Gutermann et al. (2017) berpendapat bahwa masih sangat sedikit penelitian yang menganalisis keterkaitan antara pertukaran atasan dan bawahan dengan keterikatan kerja, sedangkan kedua variabel tersebut dipandang penting dalam peningkatan kinerja dan pencapaian tujuan organisasi, maka korelasi antara kedua variabel tersebut akan diuji melalui penelitian ini. Dari hasil studi empiris yang dilakukan oleh Breevaart et al. (2013), Meng dan Wu (2015), Matta et al. (2015), dan Gutermann et al. (2017) diketahui adanya hubungan positif antara pertukaran atasan dan bawahan terhadap keterikatan kerja karyawan. Namun dalam penelitian ini, hubungan antara pertukaran atasan dan bawahan dengan keterikatan kerja diasumsikan tidak terjadi hubungan langsung dengan adanya peran pemediasi variabel perasaan kewajiban (felt obligation). Hal ini didasarkan pada studi empiris yang dilakukan oleh Eisenberger et al. (2001) dan Farh et al. (2017) yang membuktikan peran perasaan kewajiban dalam memediasi pertukaran sosial dengan perilaku keluaran karyawan.

Perasaan kewajiban berkaitan dengan hubungan resiprokal dalam hubungan pertukaran yaitu berupa proses memberi dan menerima sumber daya (Farh et al., 2017) yang menimbulkan perasaan kewajiban untuk menggunakan dan membalas sumber daya yang diberikan oleh pihak yang terlibat dalam hubungan pertukaran tersebut. Sumber daya yang dipertukarkan dalam hubungan pertukaran dapat berupa sumber daya impersonal (e.g. uang, jasa atau pelayanan, dan informasi) atau sumber daya sosio-emosional (e.g. persetujuan, penghormatan, dan kesukaan) (Eisenberger et al., 2001). Sumber daya yang berkualitas tinggi di dalam hubungan pertukaran sosial memiliki imbas terbesar terhadap kinerja apabila dikomparasikan oleh faktor-faktor lainnya (Farh et al., 2017).

Perasaan kewajiban tidak terlepas dari norma resiprokal yang dimiliki individu. Norma resiprokal akan mendasari perilaku individu dalam hubungan pertukaran dalam hal kesiapan individu membalas perlakuan yang diberikan oleh rekan kerja, pemimpin, maupun organisasi (Eisenberger et al., 2001). Eisenberger et al. (2001) menyatakan bahwa bentuk aplikasi dari norma resiprokal adalah ideologi pertukaran (exchange ideology). Ideologi pertukaran dapat membantu individu di dalam hubungan pertukaran untuk memiliki gambar diri yang positif, menghindarkan diri dari stigma yang negatif, serta mendapatkan perlakuan yang diinginkan dari hubungan pertukaran tersebut (Choi, et al, 2014 ). Ideologi pertukaran yang dimiliki seseorang akan mempengaruhi seberapa besar kemauan individu tersebut untuk membalas perlakuan individu lain di dalam hubungan pertukaran. Seorang individu yang memiliki ideologi pertukaran yang tinggi 


\section{PERFORMANCE}

Jurnal Personalia, Financial, Operasional,

Marketing dau Sistem Informasi

Performance. Volume 28 Nomor 1 Tahun 2021, 41-53

akan sangat memperhatikan tentang kapan atau apa yang dapat dibagikan kepada pihak lainnya (Idris et.al,.2016) Ideologi pertukaran juga menjadi indikator penting yang perlu mendapatkan prioritas dari pihak manajemen di dalam sebuah organisasi. Ideologi pertukaran perlu diperhatikan dalam merancang konten penugasan individu dan memberikan pekerjaan yang dirancang interdependen secara mutual, khususnya kepada karyawan yang memiliki ideologi pertukaran yang tinggi (Lin, 2007).

\section{TINJAUAN PUSTAKA DAN PERUMUSAN HIPOTESIS}

\section{Teori Pertukaran Atasan dan Bawahan}

Pertukaran atasan dan bawahan merupakan korelasi pertukaran sosial unik antara atasan dan bawahan berdasarkan peran mereka di dalam organisasi. Kualitas hubungan ini akan berbeda antar karyawan dalam satu pemimpin yang sama (Ladegard, G. and Gjerde, S., 2014, Boyas et al, 2013, \& Karatepe et al, 2013). Hubungan pertukaran sosial ini merupakan sebuah konstruk yang menekankan pada berbagai tipe dari hubungan yang berkembang di antara atasan dan bawahan dalam unit kerja mereka (Graend \& Uhl-Bien, 1995). Hubungan pertukaran atasan dan bawahan didasarkan pada teori pertukaran atasan dan bawahan dari Graen dan Cashman (1975) serta Claiborne (2015) menyatakan bahwa dalam korelasi antara atasan dengan bawahan akan terjadi hubungan diadik unik yang didasarkan teori pertukaran sosial (Pa Kim, P. S., 2008).

Hubungan yang beragam dengan bawahan akan dikembangkan oleh atasan mereka, ada yang memiliki hubungan dengan kualitas sosio-emosional yang tinggi, namun ada pula yang memiliki hubungan dengan kualitas transaksional yang rendah (Liden et al., 1997). Sehingga kualitas hubungan pertukaran atasan dan bawahan dapat dibagi menjadi dua dikotomi: kualitas rendah dan kualitas tinggi. Saat kualitas hubungan pertukaran atasan dan bawahan rendah maka yang terjadi adalah pertukaran ekonomi, di mana ketika karyawan dapat memenuhi persyaratan formal dalam kontrak kerja karyawan dan mereka akan dibayar berdasarkan apa yang telah mereka capai (Breevaart et al., 2013). Kemudian saat kualitas hubungan pertukaran atasan dan bawahan tinggi maka akan diindikasikan dengan adanya atensi dan sumber daya berlebih yang diberikan oleh atasan kepada bawahan (Meng \& Wu, 2015) dan menghasilkan perilaku karyawan yang melebihi kontrak kerja formal dengan berdasarkan pada kepercayaan, kewajiban mutual, dan saling menghormati serta dapat menghasilkan ikatan afektif (Breevaart et al., 2013). Kualitas hubungan pertukaran atasan dan bawahan akan semakin meningkat ketika setiap pihak saling membalas perlakuan yang diberikan (DeConinck, 2011). Breevaart et al. (2013) memiliki pendapat bahwa kualitas korelasi yang tinggi pada pertukaran atasan dan bawahan akan berkontribusi pada motivasi intrinsik untuk melakukan pekerjaan mereka dengan baik sebab atasan mereka akan memberikan imbalan intrinsik (e.g. pemberdayaan, pujian) dan ekstrinsik (e.g. peningkatan gaji).

\section{Pengaruh Pertukaran Atasan dan Bawahan terhadap Keterikatan Kerja}

Saat hubungan pertukaran atasan dan bawahan memiliki mutu sosio-emosional yang tinggi maka akan terjadi pertukaran atensi dan sumber daya yang berlebih di dalam hubungan pertukaran tersebut (Meng \& Wu, 2015) dan kemudian akan menghasilkan perilaku karyawan yang melebihi kontrak kerja formal dengan berdasarkan pada kepercayaan, kewajiban mutual, dan saling menghormati dan dapat menghasilkan ikatan afektif (Breevaart et al., 2013). Dilihat dari kacamata teori peran, maka konsensus peran dan perbedaan ekspektasi dalam hubungan pertukaran atasan dan bawahan memiliki konsekuensi penting terhadap keterikatan kerja karyawan, sebab peran merupakan komponen kunci dari konsep keterikatan kerja (Kahn, 1990, 1992). Dari penjelasan ini maka dapat ditarik asumsi adanya imbas positif dan signifikan antara hubungan pertukaran atasan dan bawahan terhadap keterikatan kerja.

Breevaart et al. (2013), Matta et al. (2015), Meng dan Wu (2015), serta Gutermann et al. (2017) telah melakukan penelitian empiris yang mendukung asumsi di atas dengan menemukan hubungan keterikatan kerja yang disebabkan oleh pertukaran atasan dan bawahan. Hasil ini 


\section{PERFORMANCE}

Jurnal Personalia, Financial, Operasional,

Marketing dau Sistem Informasi

Performance. Volume 28 Nomor 1 Tahun 2021, 41-53

mengindikasikan adanya pengaruh yang kuat dari pertukaran sosial dan norma resiprokal terhadap keterikatan kerja. Kemudian saat karyawan mempercayai bahwa atasan memperhatikan mereka dan memperlakukan mereka dengan adil maka karyawan tersebut akan memberikan respon dengan mempercayai atasan mereka dan memenuhi kewajiban mereka terhadap organisasi dengan cara semakin memiliki keterikatan (Meng \& Wu, 2015). Matta et al. (2015) juga menyatakan bahwa saat persepsi kualitas hubungan pertukaran atasan dan bawahan selaras maka akan meningkatkan keterikatan kerja. Begitu pula sebaliknya, jika persepsi kualitas pertukaran atasan dan bawahan tidak selaras maka akan menurunkan keterikatan kerja. Dari hubungan ini maka diasumsikan bahwa pertukaran atasan dan bawahan akan mempunyai imbas positif dan signifikan bagi keterikatan kerja, sehingga dapat dibentuk Hipotesis 1 sebagai berikut: $\mathrm{H}_{1}$ : Pertukaran atasan dan bawahan berpengaruh positif terhadap keterikatan kerja.

\section{Peran Perasaan Kewajiban dalam Memediasi Hubungan antara Pertukaran Atasan dan Bawahan terhadap Keterikatan Kerja}

Farh et al. (2017) berpendapat bahwa hubungan pertukaran sosial yang kuat akan membentuk penekanan pada timbulnya perasaan kewajiban untuk menggunakan sumber daya yang dipertukarkan di dalam hubungan tersebut. Perasaan kewajiban yang tinggi untuk membalas keuntungan yang diperoleh dalam hubungan pertukaran serta sumber daya yang dipertukarkan diasumsikan juga akan berpengaruh pada meningkatnya keterikatan kerja karyawan (Schulz et.al, 2014). Dengan kata lain, perasaan kewajiban diasumsikan akan memediasi hubungan antara pertukaran sosial yang terjadi pada atasan dan bawahan terhadap keterikatan kerja. Asumsi tersebut didukung oleh studi empiris yang dilakukan oleh Sanjeevkumar, V., (2012) yang menemukan bahwa dalam hubungan resiprokal, perasaan kewajiban untuk menggunakan sumber daya yang dipertukarkan dalam hubungan pertukaran memediasi hubungan pertukaran sosial dengan keluaran dari hubungan pertukaran tersebut (e.g. komitmen afektif, spontanitas organisasi, kinerja peran, dan perilaku penarikan). Dari hubungan tersebut maka dapat diasumsikan bahwa dalam pertukaran dalam pertukaran atasan dan bawahan terhadap keterikatan kerja tidak terjadi hubungan langsung dan akan dimediasi oleh perasaan kewajiban, sehingga dapat dibentuk Hipotesis 2 sebagai berikut:

$\mathrm{H}_{2}$ : Perasaan kewajiban memediasi hubungan pertukaran atasan dan bawahan terhadap keterikatan kerja.

\section{Peran Ideologi Pertukaran dalam Memoderasi Hubungan antara Pertukaran Atasan dan Bawahan terhadap Perasaan Kewajiban}

Witt et al. (2001) berpendapat bahwa karyawan yang berpegang pada ideologi pertukaran yang kuat akan lebih sensitif dalam mempersepsikan hubungan pertukaran dengan atasannya. Ideologi pertukaran dapat mempengaruhi orientasi individu terhadap hubungan pertukaran dapat mempengaruhi perilaku karyawan terkait pekerjaan (Ahn et al., 2018). Claiborne et al (2015) berpendapat bahwa dari beberapa studi, diketahui bahwa ideologi pertukaran dapat mempengaruhi pembentukan sikap dan perilaku kerja karyawan dan persepsi mereka terhadap organisasi. Individu yang berpegang pada ideologi pertukaran yang tinggi akan sangat memperhatikan tentang kapan dan apa yang hendak dibagikan kepada orang lain (Pa Kim, P. S., 2008) dan sangat berpusat pada keuntungan personal (Lin, 2007). Sedangkan individu yang memiliki ideologi pertukaran yang rendah tidak termotivasi oleh kepentingan diri sendiri (Witt, 1992). Dalam studi empiris yang dijalankan oleh Eisenberger et al. (2001) ditemukan bahwa dalam korelasi resiprokal, ideologi pertukaran memoderasi hubungan antara dukungan organisasi yang dipersepsikan dengan perasaan kewajiban. Dari hubungan tersebut maka dapat diasumsikan bahwa hubungan antara pertukaran atasan dan bawahan dengan perasaan kewajiban akan lebih kuat saat dimoderasi oleh ideologi pertukaran yang tinggi, sehingga dapat dibentuk Hipotesis 3 sebagai berikut: 
$\mathrm{H}_{3}$ : Ideologi pertukaran memoderasi korelasi antara pertukaran atasan dan bawahan perasaan kewajiban.

\section{METODE PENELITIAN}

\section{Sampel dan Prosedur}

Penelitian ini menggunakan sampel yang diambil dari pegawai Badan Pemeriksa Keuangan (BPK RI) pada level staf di Unit Pelaksana Tugas Penunjang dan Unit Pelaksana Tugas Pendukung. Dari 110 kuesioner didistribusikan lansung, dikembalikan sebanyak 88 kuesioner dan yang dapat dianalisis lebih lanjut sebanyak 69 kuesioner. Untuk kuesioner yang didistribusikan melalui daring diperoleh 251 kuesioner dan yang dapat dianalisis lebih lanjut sebanyak 145 kuesioner. Total kuesioner yang dapat dipergunakan dalam melakukan analisis adalah sebanyak 361 kuesioner.

\section{Pengukuran \\ Variabel Pertukaran Atasan dan Bawahan}

Variabel pertukaran atasan dan bawahan (PAB) ditakar memakai 7 butir pertanyaan LMX-7 yang diekspansi oleh Graen dan Uhl-Bien (1995) yang telah dimodifikasi oleh DeConinck (2011) untuk mengukur persepsi bawahan terkait kualitas hubungan pertukaran atasan dan bawahan yang terjadi di antara mereka.

\section{Variabel Keterikatan Kerja}

Variabel keterikatan kerja (KK) ditakar memakai 9 butir pertanyaan yang diekspansi oleh Schaufeli et al. (2006) yang disebut dengan Utrecht Work Engangement Scale (UWES-9). Kuesioner ini digunakan untuk mengukur persepsi bawahan terhadap keterikatan kerja yang mereka miliki.

\section{Variabel Perasaan Kewajiban}

Variabel perasaan kewajiban (PK) ditakar memakai 7 butir pertanyaan yang diekspansi oleh Eisenberger et al. (2001) untuk mengukur perasaan kewajiban dalam membalas perlakuan atau menggunakan sumber daya yang dipertukarkan dalam hubungan pertukaran atasan dan bawahan.

\section{Variabel Ideologi Pertukaran}

Variabel ideologi pertukaran (IP) ditakar memakai 8 butir pertanyaan yang diekspansi oleh Eisenberger et al. (2001) untuk mengukur tingkat ideologi pertukaran yang dimiliki oleh bawahan.

\section{Teknik Pengujian Hipotesis}

Untuk menguji hubungan antara variabel pertukaran atasan dan bawahan terhadap keterikatan kerja dengan perasaan kewajiban sebagai pemediasi (Hipotesis 1 dan Hipotesis 2) dalam penelitian ini akan menggunakan regresi bertingkat (hierarchical regression) yang berfungsi untuk memprediksi pengaruh hubungan antar variabel disertai adanya variabel pemediasi dan pemoderasi. Sedangkan untuk pengujian variabel ideologi pertukaran sebagai variabel pemoderasi pengaruh pertukaran atasan dan bawahan dan perasaan kewajiban (Hipotesis 3) akan menggunakan Moderated Regression Analysis (MRA). Pengujian ini dimaksudkan untuk menguji pengaruh ideologi pertukaran (sebagai variabel moderator) dalam memoderasi pertukaran atasan dan bawahan (sebagai variabel independen) terhadap perasaan kewajiban (sebagai variabel pemediasi). Dua jenis tersebut pengujian mengikuti standar pengujian variabel mediasi dan moderasi oleh Baron dan Kenny (1986).

Untuk pengujian variabel pemediasi yang pertama dilakukan adalah dengan menguji efek langsung antara pertukaran atasan dan bawahan terhadap keterikatan kerja, kemudian dilanjutkan dengan menguji pengaruh langsung pertukaran atasan dan bawahan terhadap perasaan kewajiban, selanjutnya menguji pengaruh langsung perasaan kewajiban terhadap 


\section{PERFORMANCE}

Jurnal Personalia, Financial, Operasional,

Marketing dau Sistem Informasi

Performance. Volume 28 Nomor 1 Tahun 2021, 41-53

keterikatan kerja. Kemudian menguji efek variabel pemediasi berupa perasaan kewajiban yang diregresi secara bersamaan dengan variabel pertukaran atasan dan bawahan terhadap keterikatan kerja.

Untuk pengujian variabel pemoderasi yang pertama dilakukan adalah dengan melakukan proses proses mean-centering dengan mengurangkan jumlah skor jawaban setiap variabel dengan rata-rata setiap variabel. Proses ini bertujuan untuk menghindari multikolinearitas antara prediktor dan interaksinya serta mempermudah peneliti untuk melakukan interpretasi hasil (Aiken \& West, 1991). Setelah mean-centering dilakukan, maka seluruh variabel dalam model tidak akan memiliki multikolinearitas (nilai tolerance $>0,10$ dan VIF $<10$ ), sehingga secara statistik dinyatakan bahwa imbas variabel independen dan variabel pemoderasi terhadap variabel pemediasi dapat dibedakan secara jelas antar variabel di dalam model. Langkah berikutnya adalah dengan menguji pengaruh langsung pertukaran atasan dan bawahan terhadap perasaan kewajiban serta menguji pengaruh langsung ideologi pertukaran terhadap perasaan kewajiban. Kemudian menguji efek pemoderasi dari interaksi antara pertukaran atasan dan bawahan serta ideologi pertukaran terhadap keterikatan kerja.

\section{HASIL DAN PEMBAHASAN}

Berdasarkan uji validitas yang dilakukan, menghasilkan 31 item instrumen penelitian, terdapat 7 item (PAB1, KK5, PK3, PK7, IP3, IP4, IP8) yang memiliki nilai factor loading $\geq 0$, 5 sehingga 7 item tersebut tidak diikutkan dalam proses pengujian berikutnya. Uji reliabilitas menghasilkan nilai Cronbach Alpha $\geq 0,6$ sehingga kesimpulan yang dapat ditarik adalah keempat instrumen pengukuran variabel ini pantas untuk mengukur konstruk penelitian ini.

\section{Hasil Uji Hipotesis 1 dan Hipotesis 2}

Dari pengujian Hipotesis 1 (Tabel 1 ) dapat dilihat bahwa variabel pertukaran atasan dan bawahan memiliki imbas positif dan signifikan terhadap variabel keterikatan kerja $(B=0,351$; $p<0,001)$. Hasil koefisien regresi juga menunjukkan bahwa variabel pertukaran atasan dan bawahan dapat menjelaskan keterikatan kerja sebesar $11,9 \%\left(\Delta R^{2}=0,119\right)$, selanjutnya sebesar $88,1 \%$ adalah sisanya yang diakibatkan oleh variabel lain yang tidak tertera dalam bentuk penelitian ini. Jadi, dapat disimpulkan bahwa Hipotesis 1 terdukung.

Tabel 1. Hasil Uji Hipotesis 1

\begin{tabular}{ccccc} 
& Variabel & $b$ & $t$ & Sig. \\
\hline $\mathrm{PAB}$ & & 0,351 & 5,465 & 0,000 \\
\hline$\Delta R^{2}$ & $=0,119$ & & & \\
\hline $\mathrm{F}$ & $=29,865$ & & & \\
\hline
\end{tabular}

Keterangan: $p<0,01$

Sumber: Data diolah (2021)

Selanjutnya pengujian Hipotesis 2 dilakukan berdasarkan prosedur milik Baron dan Kenny (1986), dimana dilakukan uji pengaruh variabel dependen terhadap variabel pemediasi, yang dilanjutkan uji variabel pemediasi terhadap variabel dependen yang dapat dilihat melalui Tabel 2 . pada bagian pengujian terpisah. Pada Tabel 2.2 diketahui bahwa variabel pertukaran atasan dan bawahan memiliki imbas positif dan signifikan pada variabel perasaan kewajiban $(B=0,581$; $p<0,001)$. Sedangkan pengujian pengaruh variabel perasaan kewajiban terhadap variabel keterikatan kerja memiliki hasil bahwa kedua variabel tersebut berpengaruh positif dan juga signifikan ( $6=0,343 ; p<0,001)$.

Terakhir langkah yang dilakukan adalah melakukan uji pengaruh variabel pertukaran atasan dan bawahan serta variabel perasaan kewajiban secara bersamaan terhadap variabel keterikatan kerja. Hasil uji Hipotesis 2 dapat dilihat dalam Tabel 2. pada bagian pengujian efek pemediasi, di 
Jurnal Personalia, Financial, Operasional,

Marketing dau Sistern Informasi

Performance. Volume 28 Nomor 1 Tahun 2021, 41-53

mana diketahui bahwa variabel perasaan kewajiban memediasi secara parsial hubungan antara variabel pertukaran atasan dan bawahan terhadap keterikatan kerja $(\theta=0,230 ; p<0,01$ dan $B=0,209 ; p<0,01)$. Hal ini diketahui tidak adanya perubahan signifikansi dalam hubungan variabel pertukaran atasan dan bawahan terhadap keterikatan kerja, baik sebelum $(\beta=0,351 ; p<0,001)$ maupun sesudah $(B=0,230 ; p<0,01$ dan $B=0,209 ; p<0,01)$ variabel perasaan kewajiban dimasukkan dalam pengujian sebagai pemediasi. Jadi, kesimpulannya adalah mendukung Hipotesis 2, namun efek pemediasi dari perasaan kewajiban bersifat parsial yang mengindikasikan bahwa tanpa adanya perasaan kewajiban sebagai variabel pemediasi, maka pertukaran atasan dan bawahan dapat memiliki imbas langsung yang bersifat positif dan signifikan terhadap keterikatan kerja.

Tabel 2. Hasil Uji Hipotesis 2

\begin{tabular}{|c|c|c|c|c|}
\hline & riables & 6 & $t$ & Sig. \\
\hline \multicolumn{5}{|c|}{ Pengujian Terpisah } \\
\hline PAB & & 0,581 & 10,396 & 0,000 \\
\hline$\Delta R^{2}$ & $=0,335$ & & & \\
\hline $\mathrm{F}$ & $=108,078$ & & & \\
\hline PK & & 0,383 & 5,312 & 0,000 \\
\hline$\Delta R^{2}$ & $=0,113$ & & & \\
\hline $\mathrm{F}$ & $=28,215$ & & & \\
\hline
\end{tabular}

\section{Pengujian Efek Pemediasi}

\begin{tabular}{lllll}
\hline \hline $\mathrm{PAB}$ & & 0,230 & 2,952 & 0,004 \\
\hline $\mathrm{PAB}$ dan PK & & 0,209 & 2,686 & 0,008 \\
\hline$\Delta R^{2}$ & $=0,144$ & & & \\
\hline$F$ & $=18,977$ & & &
\end{tabular}

Keterangan: $p<0,01$

Sumber: Data diolah (2021)

\section{Hasil Uji Hipotesis 3}

Berdasarkan hasil pengujian regresi dengan metode MRA, diperoleh hasil bahwa efek interaksi antara variabel ideologi pertukaran sebagai variabel pemoderasi dan variabel pertukaran atasan dan bawahan terhadap variabel perasaan kewajiban (Tabel 3) menunjukan hasil yang bersifat tidak siginifikan $(\theta=0,077 ; t=0,275 ; p>0,10)$. Berdasarkan hasil uji regresi tersebut dapat disimpulkan bahwa tidak mendukung Hipotesis 3 .

Tabel 3. Hasil Uji Hipotesis 3

\begin{tabular}{llccc}
\hline & Variabel & $b$ & $T$ & Sig. \\
\hline PAB & & 0,528 & 2,685 & 0,008 \\
\hline IP & & $-0,072$ & $-0,325$ & 0,746 \\
\hline PABxIP & $=0,329$ & 0,077 & 0,275 & 0,784 \\
\hline$\Delta R^{2}$ & $=35,759$ & & & \\
\hline$F$ & & & &
\end{tabular}

Keterangan: $p>0,10$

Sumber: Data diolah (2019)

\section{KESIMPULAN}

Hasil penelitian ini memberikan tiga bukti empiris terkait dengan pengaruh atasan dan bawahan yang ditukar dengan keterikatan kerja karyawan melalui adanya perasaan kewajiban 


\section{PERFORMANCE}

Jurnal Personalia, Financial, Operasional,

Marketing dau Sistem Informasi

Performance. Volume 28 Nomor 1 Tahun 2021, 41-53

yang memediasi secara parsial hubungan antar kedua variabel. Namun ideologi pertukaran tidak terbukti memoderasi hubungan antara pertukaran atasan dan bawahan terhadap perasaan kewajiban.

Temuan empiris pertama penelitian ini menghasilkan dukungan terhadap imbas positif dan signifikan dalam korelasi pada pertukaran atasan dan bawahan terhadap keterikatan kerja. Saat hubungan pertukaran atasan dan bawahan bermutu tinggi, hal tersebut akan meningkatkan keterikatan kerja karyawan

Temuan empiris kedua, hasil penelitian ini mendukung adanya efek pemediasi perasaan kewajiban dalam hubungan antara pertukaran atasan dan bawahan terhadap keterikatan kerja. Namun efek pemediasi yang dimiliki oleh perasaan kewajiban dalam penelitian ini bersifat parsial, hal ini dapat diartikan adanya imbas langsung pertukaran atasan dan bawahan pada keterikatan kerja, serta dimungkinkan adanya variabel-variabel lain yang memediasi di luar bentuk dalam penelitian ini. Saat individu berpikir bahwa hubungan pertukaran yang dialaminya berada dalam konteks organisasional (e.g. hubungan rekan kerja, hubungan atasan-bawahan) akan merasa kurang termotivasi dan kurang memiliki perasaan kewajiban untuk melakukan hubungan resiprokal, sebaliknya saat individu tersebut berpikir dalam konteks personal (e.g. teman, kenalan) maka mereka akan lebih termotivasi dan merasa berkewajiban untuk melakukan hubungan resiprokal (Idris Osman et.al 2016).

Ketiga, hasil penelitian ini tidak mendukung adanya efek pemoderasi oleh ideologi pertukaran pada bentuk yang dipakai dalam penelitian ini, sehingga dimungkinkan adanya hubungan langsung antara ideologi pertukaran dengan perasaan kewajiban serta pertukaran atasan dan bawahan (Claiborne.et.al 2015). Hubungan ini bersifat negatif karena individu yang memiliki ideologi pertukaran yang tinggi akan lebih memperhatikan tentang apa yang mereka dapatkan daripada apa yang dapat mereka berikan, sehingga mereka akan merasa kurang memiliki perasaan kewajiban terhadap organisasi (Choi et.al 2014) Disamping itu, jika individu berpikir bahwa mereka melakukan hubungan pertukaran dalam konteks organisasional (e.g. hubungan rekan kerja, hubungan atasan-bawahan), maka akan memperlemah norma resiprokal (e.g. ideologi pertukaran) yang dimiliki individu tersebut. Hasil pengujian Hipotesis 3 kemungkinan juga dipengaruhi oleh karakteristik unik dari sampel yang dipakai. Sampel dalam penelitian ini mengambil pegawai BPK di mana pada lingkungan kerja intansi pemerintahan di Indonesia dimungkinan memiliki kultur dan budaya kerja yang berbeda dari sektor swasta. Demikian hal ini mungkin memiliki pengaruh yang berbeda apabila dikomparasikan dengan studi-studi empiris sebelumnya. Berdasarkan hasil pengujian, dimungkinkan pada kondisi kerja di BPK ideologi pertukaran tidak berpengaruh dalam hubungan pertukaran sosial, sehingga hubungan resiprokal yang terjadi mungkin hanya sebatas pertukaran bersifat transaksional saja. Pegawai BPK kemungkinan tidak dapat atau tidak diberi kesempatan mempergunakan ideologi pertukaran yang dimiliki oleh setiap individu untuk memilih melakukan hubungan resiprokal atau tidak.

\section{Implikasi Penelitian}

Penelitian ini memberikan kontribusi empiris dalam perkembangan literatur yang berkaitan dengan variabel-variabel dalam model penelitian. Penelitian ini memberikan bukti empiris mengenai dampak dari pertukaran atasan dan bawahan terhadap keterikatan kerja, hal ini mendukung penelitian-penelitian empiris yang telah dilakukan sebelumnya dan menguatkan teori pada literatur pertukaran sosial, khususnya pertukaran atasan dan bawahan.

Di sisi lain, dapat dikatakan bahwa penelitian ini mendukung adanya korelasi tidak langsung antara atasan dan bawahan yang ditukar dengan keterikatan kerja dengan adanya perasaan kewajiban sebagai pemediasi. Walaupun dalam penelitian ini ditemukan bahwa perasaan kewajiban hanya memoderasi secara parsial, namun hal ini semakin memperkaya dari hasil studi empiris sebelumnya. Kemudian penelitian ini juga memperkaya studi empiris yang dilakukan sebelumnya tentang efek utama (bukan efek pemoderasi) dari ideologi pertukaran, di mana dimungkinkan adanya hubungan langsung ideologi pertukaran dengan perasaan kewajiban serta 


\section{PERFORMANCE}

Jurnal Personalia, Financial, Operasional,

Marketing dau Sistem Informasi

Performance. Volume 28 Nomor 1 Tahun 2021, 41-53

pertukaran atasan dan bawahan. Sebab dalam penelitian ini ditemukan bahwa ideologi pertukaran tidak memiliki efek pemoderasi.

Diharapkan penelitian mampu berkontribusi sebagai acuan yang dapat dipertimbangkan oleh manajer untuk menciptakan kondisi yang mampu meningkatkan keterikatan kerja karyawan dengan cara meningkatkan kualitas pertukaran atasan dan bawahan dalam lingkungan organisasi. Kualitas pertukaran atasan dan bawahan akan meningkat seiring dengan hubungan resiprokal yang terjadi, di mana kualitas pertukaran tersebut akan meningkatkan perasaan kewajiban karyawan untuk melakukan hubungan resiprokal dan berdampak pada peningkatan keterikatan kerja dan kinerja karyawan. Namun manajer perlu memperhatikan faktor-faktor lain yang mungkin mempengaruhi hubungan antara pertukaran atasan dan bawahan terhadap keterikatan kerja, sebab dari penelitian ini diketahui bahwa perasaan kewajiban hanya memediasi secara parsial.

Manajer juga perlu untuk memperhatikan pentingnya ideologi pertukaran dari setiap karyawan dalam hubungan pertukaran atasan dan bawahan, sebab dimungkinkan variabel ini mempengaruhi secara langsung hubungan pertukaran sosial dan perasaan kewajiban secara negatif. Sebab jika manajer mengabaikan ideologi pertukaran maka dapat membuat pengamatan akan hubungan pertukaran sosial di dalam organisasi menjadi tidak lengkap.

\section{Keterbatasan dan Saran}

Penelitian ini berupaya secara optimal untuk memberikan hasil penelitian yang terbaik. Namun penelitian inti tidak terlepas dari keterbatasan yang harus diperhatikan dan diperbaiki dalam penelitian berikutnya. Pertama, penelitian ini menggunakan teknik cross-sectional dalam mengumpulkan data sehingga hanya dapat menangkap kejadian pada waktu tertentu. Penelitian berikutnya diharapkan dapat menggunakan teknik longitudinal sehingga dapat memberikan pandangan yang lebih baik terhadap variabel-variabel yang diteliti.

Kedua, pengukuran persepsi terhadap pertukaran atasan dan bawahan hanya melihat dari sisi karyawan saja. Penelitian berikutnya diharapkan dapat menggunakan pengukuran kualitas pertukaran atasan dan bawahan dari dua 2 sisi, yaitu dengan melihat persepsi dari atasan dan persepsi dari bawahan agar dapat dilihat kesepahaman di antara kedua belah pihak terhadap kualitas pertukaran atasan dan bawahan yang terjadi di antara mereka.

Ketiga, penelitian ini menggunakan instrumen penelitian ideologi pertukaran yang lebih condong untuk mengukur ideologi pertukaran antara individu dengan organisasi. Penelitian berikutnya dapat mencoba menggunakan instrumen penelitian ideologi pertukaran yang dikembangkan secara spesifik untuk mengukur hubungan pertukaran dalam konteks individu yang memungkinkan adanya hasil yang berbeda.

Keempat, penelitian ini mengambil sampel pegawai BPK di mana pada lingkungan kerja intansi pemerintahan dimungkinan memiliki kultur dan budaya kerja yang berbeda dari sektor swasta. Mungkin hal ini akan memiliki pengaruh yang berbeda apabila dikomparasikan pada studistudi empiris sebelumnya. Diharapkan pada penelitian berikutnya dapat menggunakan sampel dari kultur dan budaya kerja pada lingkungan yang berbeda (e.g. organisasi swasta, organisasi non profit) dengan tujuan agar dapat memberikan generalisasi temuan penelitian yang lebih baik.

\section{DAFTAR PUSTAKA}

Ahn, J., Lee, S., dan Yun, S. (2018), Leaders' Core Self-Evaluation, Ethical Leadership, and Employees' Job Performance: The Moderating Role of Employees' Exchange Ideology, Journal Business Ethics, 148, 457-470.

Avery, D. R., McKay, P. F., dan Wilson, D. C. (2007), Engaging the Aging Workforce: The Relationship Between Perceived Age Similarity, Satisfaction with Coworkers, and Employee Engagement, Journal of Applied Psychology, 92(6), 1542-1556. 


\section{PERFORMANCE}

Jurnal Personalia, Financial, Operasional,

Marketing dau Sistem Informasi

Performance. Volume 28 Nomor 1 Tahun 2021, 41-53

Bakker, A. B. dan Leiter, M. P. (2010), Work Engagement: A Handbook of Essential Theory and Research, New York, Psychology Press.

Baron, R. M. dan Kenny, D. A. (1986), The Moderator-Mediator Variable Distiction in Social Psychological Research: Conceptual, Strategic, and Statistical Consideration, Journal of Personality and Social Psychology, 51, 1173-1182.

Belmi, P. dan Pfeffer, J. (2015), How "Organization" can Weaken the Norm of Reciprocity: The Effects of Attributions for Favors and a Calculative Mindset, Academy of Management Discoveries, 1(1), 36-57.

Boyas, J. F., Wind, L. H. and Ruiz, E., 2013. Organizational Tenure Among Child Welfare Workers, Burnout, Stress and Intent to Leave: Does Employment-Based Social Capital Make A Difference? Children and Youth Services Review, 35 1657-1669.

Bourdieu, P. (1985), The Forms of Capital, dalam Richardson, J. G. (Ed.), Handbook of Theory and Research for Sociology of Education, New York, NY, Greenwood, 241-258.

Breevaart, K., Bakker, A. B., Demerouti, E., dan van den Heuvel, M. (2013). Leader-Member Exchange, Work Engagement, and Job Performance, Journal of Managerial Psychology, 30(7), 754-770.

Cogliser, C. C., Schriesheim, C. A., Scandura, T. A., dan Gardner, W. L. (2009), Balance in Leader and Follower Perceptions of Leader-Member Exchange: Relationships with Performance and Work Attitudes, The Leadership Quarterly, 20, 452-465.

Cole, M. S., Bernerth, J. B., Walter, F., dan Holt, D. T. (2010), Organizational Justice and Individuals' Withdrawal: Unlocking the Influence of Emotional Exhaustion, Journal of Management Studies, 47, 36-390.

Cole, M. S., Schaninger, W. S., dan Harris, S. G. (2002), The Workplace Social Exchange Network: A Multilevel, Conceptual Examination, Group and Organization Management, 27, 142-167.

Cooper D. R. dan Schindler, P. S. (2014), Business Research Methods (Eleventh Edition), The McGraw-Hill/Irwin.

Cropanzano, R. dan Mitchell, M. S. (2005), Social Exchange Theory: An Interdisciplinary Review, Journal of Management, 31, 874-900.

Choi, Y. and Lee, D., 2014. Psychological Capital, Big Five Traits and Employee Outcomes. Journal of Managerial Psychology, 29(2) $122-140$.

Claiborne, N., Auerbach, C., Zeitlin, W. and Lawrence. C. K., 2015. Climate Factors Related to Intention to Leave in Administrators and Clinical Professionals. Children and Youth Services Review, 51, 18-25.

DeConinck, J. B. (2011), The Effects of Leader-Member Exchange and Organizational Identification on Performance and Turnover Among Salepeople, Journal of Personal Selling and Sales Management, 31(1), 21-34.

Demerouti, D., Bakker, A. B., Nachreiner, F., dan Schaufeli, W. B. (2001), The Job DemandsResources Model of Burnout, Journal of Applied Psychology, 86(3), 499-512. 
Jurnal Personalia, Financial, Operasional,

Marketing dau Sistem Informasi

Performance. Volume 28 Nomor 1 Tahun 2021, 41-53

Dulebohn, J. H., Bommer, W. H., Liden, R. C., Brouer, R. L., dan Ferris, G. R. (2012), A Meta-analysis of Antecedents and Consequences of Leader-Member Exchange: Integrating the Past with an Eye Toward the Future, Journal of Management, 38(6), 1715-1759.

Eisenberger, R., Armeli, S., Rexwinkel, B., Lynch, P. D., dan Rhoades, L. (2001), Reciprocation of Perceived Organizational Support, Journal of Applied Psychology, 86(1), 42-51.

Farh, C. I. C., Lanaj, K., dan Ilies, R. (2017), Resource-Based Contigencies of When Team-Member Exchange Helps Member Performance in Teams, Academy of Management Journal, 60(3), 1117-1137.

Farmer, S. M. dan Aguinis, H. (2005), Accounting for Subordinate Perceptions of Supervisor Power: An Identity-Dependence Model, The Journal of Applied Psychology, 90, 1069-1083.

Ford, L. R., Wilkerson, S., Seers, A., dan Moormann, T. (2014), The Generation of Influence: Effects of Leader-Member Exchange and Team-Member Exchange, Journal of Strategic and International Studies, 9, 5-14.

Gerstner, C. R. dan Day, D. V. (1997), Meta-Analytic Review of Leader-Member Exchange Theory: Correlates and Construct Issues, journal of Applied Psychology, 82(6), 827-844.

Gutermann, D., Lehman-Willenbrock, N., Boer, D., Born, M., dan Voelpel, S. C. (2017), How Leader Affect Followers' Work Engagement and Performance: Integrating Leader-Member Exchange and Crossover Theory, British Journal of Management, 28, 299-314.

Graen, G. B. dan Uhl-Bien, M. (1995), Relationship-based Approach to Leadership: Development of Leader-Member Exchange (LMX) Theory of Leadership Over 25 Years: Applying a MultiLevel Multi-Domain Perspective, The Leadership Quarterly, 6, 219-247.

Hair, J. F, Black, W. C., Babin, B. J., dan Anderson, R. E. (2010), Multivariate Data Analysis (Seventh Edition), Pearson.

Halbesleben, J. R., Harvey, J., dan Bolino, M. (2009), Too Engaged? A Conversation of Resources View of the Relationship Between Work Engagement and Work Interference with Family, Journal of Applied Psychology, 94, 1452-1465.

Harris, K. J., Wheeler, A. R., dan Kacmar, K. M. (2009), Leader-Member exchange and Empowerment: Direct and Interactive Effects on Job Satisfaction, Turnover Intentions, and Performance, The Leadership Quarterly, 20, 371-382.

Huang, X., Chan, S. C. H., Lam, W., dan Nan, X. (2010), The Joint Effect of Leader-Member Exchange and Emotional Intelligence on Burnout and Work Performance in Call Centers in China, The International Journal of Human Resource Management, 21(7), 1124-1144.

Idris Osman, Fauziah Noordina, Normala Dauda, Mohd Zailani Othman (2016) The Dynamic Role of Social Exchange and Personality in Predicting Turnover Intentions among Professional Workers. Procedia Economics and Finance 35 page 541.

Ladegard, G. and Gjerde, S., 2014. Leadership Coaching, Leader Role-Efficacy, and Trust in Subordinates. A mixed methods study assessing leadership coaching as a leadership development tool. The Leadership Quarterly 25, 631-646. 
Jurnal Personalia, Financial, Operasional,

Marketing dau Sistem Informasi

Performance. Volume 28 Nomor 1 Tahun 2021, 41-53

Kahn, W. A. (1992), To be Fully There: Psychological Presence at Work, Human Relations, 45, 321724.

Karatepe, O. M., 2013. High-Performance Work Practices, Work Social Support and Their Effects on Job Embeddedness and Turnover Intentions. International Journal of Contemporary Hospitality Management, 25(6) $903-921$.

Ilies, R., Nahrgang, J. D., dan Morgeson, F. P. (2007), Leader-Member Exchange and Citizenship Behavior: A Meta-Analysis, Journal of Applied Psychology, 92(1), 269-277.

Laksana, R.D., Mayasari, V., Setyanto, R.P. (2020) Model of disorientation and disqualification of peripheral services in public services on local government device work units in Central Java, Indonesia. WSEAS Transactions on Business and Economics, 17, pp. 842-848, 82

Liao, F. Y., Yang, L. Q., Wang, M., Drown, D., dan Shi, J. (2013), Team-Member Exchange and Work Engagement: Does Personality Make a Difference?, Journal of Business and Psychology, 28(1), 64-77.

Lin, C. P. (2007), To Share or Not to Share: Modeling Knowledge Sharing Using Exchange Ideology as a Moderator, Personnel Review, 36(3), 457-475.

Matta, F. L., Scott, B. A., Koopman, J., dan Conlon, D. E. (2015), Does Seeing "Eye to Eye" Affect Work Engagement and Organizational Citizenship Behavior? A Role Theory Perspective on LMX Agreement, Academy of Management Journal, 58(6), 1686-1708.

Meng, F. dan Wu, J. (2015), Merit Pay Fairness, Leader-Member Exchange, and Job Engagement: Evidence from Mainland China, Review of Public Personnel Administration, 35(1), 47-69.

Molm, L. D., Takahashi, N., dan Peterson, G. (2003), In the Eye of the Beholder: Procedural Justice in Social Exchange, American Sociological Review, 68, 128-152.

Neuman, W. L. (2014), Social Research Methods: Qualitative and Quantitative Approaches (International Version), Pearson Education Limited.

Redman, T. dan Snape, E. (2005), Exchange Ideology and Member-Union Relationships: An Evaluation of Moderation Effects, Journal of Applied Psychology, 90(4), 765-73.

Rich, B. L., Lepine, J. A., dan Crawford, E. R. (2010), Job Engagement: Antecedents and Effects on Job Performance, Academy of Management Journal, 53(3), 617-635.

Robinson, D., Perryman, S., dan Hayday, S. (2004), The Drivers of Employee Engagement, Brighton, UK, Institute for Employment Studies.

Saks, A. M. (2006), Antecedents and Consequences of Employee Engagement, Journal of Managerial Psychology, 21, 600-619.

Salanova, M., Agut, S., dan Peiro, J. M. (2005), Linking Organizational Resources and Work Engagement to Employee Performance and Customer Loyalty: The Mediation of Service Climate, Journal of Applied Psychology, 90, 1217-1227.

Sanjeevkumar, V., 2012. A Study on Employee's Intention to Stay in Public Companies, Kedah, Malaysia. Zenith International Journal of Business Economics \& Management Research, 2 (4). 
Jurnal Personalia, Financial, Operasional,

Marketing dau Sistem Informasi

Performance. Volume 28 Nomor 1 Tahun 2021, 41-53

Schulz, S. A., Luthans, K. W. and Messersmith, J. G., 2014. Psychological Capital: A New Tool for Driver Retention. International Journal of Physical Distribution \& Logistics Management, $44(8 / 9) 621-634$.

Sekaran, U. dan Bougie, R. (2016), Research Methods for Business (Seventh Edition), John Wiley \& Sons, Ltd.

Schaufeli, W. B. dan Bakker, A. B. (2006), The Measurement of Work Engagement With a Short Questionnaire, Educational and Psychological Measurement, 66(4), 701-716.

Scott, B. A. dan Colquitt, J. A. (2007), Are Organizational Justice Effect Bounded by Individual Differences? An Examination of Equity Sensitivity, Exchange Ideology, and the Big Five, Group and Organization Management, 32, 290-325.

Takeuchi, R., Yun, S., dan Wong, K. F. E. (2011), Social Influence of a Coworker: A Test of the Effect of Employee and Coworker Exchange Ideologies on Employees' Exchange Qualities, Organizational Behavior and Human Decision Processes, 115(2), 226-237.

Volmer, J., Spurk, D., dan Niessen, C. (2012), Leader-Member Exchange (LMX), Job Autonomy, and Creative Work Involvement, The Leadership Quarterly, 23, 456-465.

Wang, H., Law, K. S., Hackett, R. D., Wang, D., dan Chen, Z. X. (2005), Leader-Member Exchange as a Mediator of the Relationship Between Transformational Leadership and Follower's Performance, and Organizational Citizenship Behavior, Academy of Management Journal, 48(3), 420-432.

Wayne, S. J., Shore, L. M., dan Liden, R. C. (1997), Perceived Organizational Support and LeaderMember Exchange: A Social Exchange Perspective, Academy of Management Journal, 40(1), 82-111.

Wijaya, N. H. S. (2018), Proactive Personality, LMX, and Voice Behavior: Employee-Supervisor Sex (Dis) similarity as a Moderator, Management Communication Quarterly, 1-5.

Wilson, K. S., Sin, H. P., dan Conlon, D. E. (2010), What About the Leader in Leader-Member Exchange? The Impact of Resource Exchanges and Substitutability on the Leader, Academy of Management Review, 35, 358-372.

Witt, L. A. dan Wilson, J. W. (1990), Income Sufficiency as a Predictor of Job Satisfaction and Organizational Commitment: Dispositional Differences, Journal of Social Psychology, 130(2), 267-268.

Yulianto, H. (2014), Pengaruh Organizational Justice sebagai Variabel Pemediasi Hubungan Leader-Member Exchange (LMX) dengan Kepuasan Kerja, Komitmen Organisasional, dan Turnover Intentions, Tesis Gelar Master, Universitas Gadjah Mada. 